\title{
PERANAN KELUARGA, SEKOLAH, DAN MASYARAKAT DALAM IMPLEMENTASI PENDIDIKAN TRI KAYA PARISUDHA SEBAGAI LANDASAN PEMBENTUKAN KARAKTER GENERASI MUDA
}

\author{
Oleh: Putu Sabda Jayendra ${ }^{13}$
}

\begin{abstract}
Abstrak
Pendidikan merupakan suatu proses yang didapat dari sejak manusia ada dalam kandungan sampai dengan seumur hidupnya. Manusia yang lahir tidak akan dapat memanusia dengan sendirinya. Oleh sebab itu pendidikan merupakan jalan yang paling pertama dan utama untuk memanusiakan manusia, sehingga nantinya manusia itu tidak hanya menjadi manusia yang memiliki ilmu pengetahuan yang tinggi, namun juga menjadi manusia yang memiliki kepribadian yang baik dan berakhlak mulia. Dalam perspektif Hindu, menyikapi fenomena penyimpangan perilaku yang banyak dilakukan oleh para peserta didik dewasa ini, haruslah dimulai sejak dini dengan mengimplementasikan pendidikan Tri Kaya Parisudha, yaitu membiasakan anak untuk berpikir, berkata, dan berbuat yang baik dan benar, dengan mengoptimalkan peran keluarga, sekolah, dan masyarakat.

Kata kunci: Pendidikan, Tri Kaya Parisudha, Keluarga, Sekolah, Masyarakat.
\end{abstract}

\section{PENDAHULUAN}

Pendidikan selain mencakup proses transfer dan transmisi ilmu pengetahuan juga merupakan proses yang sangat strategis dalam menanamkan nilai dalam rangka pembudayaan anak manusia. Undang-Undang Sisdiknas 20/2003 menyatakan bahwa "pendidikan adalah usaha sadar dan terencana untuk mewujudkan suasana belajar dan proses pembelajaran agar peserta didik secara aktif mengembangkan potensi dirinya untuk memiliki kekuatan spiritual keagamaan, pengendalian diri, kepribadian, kecerdasan, akhlak mulia, serta keterampilan yang diperlukan dirinya, masyarakat, bangsa, dan negara" (Sisdiknas, No. 20 tahun 2003). Beranjak dari pernyataan tersebut, maka pendidikan tidak hanya bertujuan untuk menggali dan mengembangkan potensi dan kecerdasan anak didik, namun juga yang lebih ditekankan adalah pembentukan kepribadian serta penanaman nilai-nilai budaya demi terbentuknya manusia yang memiliki akhlak mulia.

Adanya fenomena mulai dari merosotnya moral peserta didik hingga munculnya tindak kekerasan mengisyaratkan bahwa pendidikan karakter menjadi satu hal yang tidak boleh dikesampingkan dalam proses pembelajaran. Kenyataan yang terjadi di masyarakat adalah setiap perilaku dan sikap beringas yang tampak pada peserta didik senantiasa dikaitkan dengan kegagalan dari mata pelajaran agama (Tanu, 2010:159).

Terkait dengan hal tersebut, pendidikan agama memiliki peranan yang sangat penting dalam membangun karakter anak didik sebagai generasi muda bangsa. Ardika (dalam Sedhawa, 2006:29) agama berperan mengendalikan dan menopang tata susila dan tata sosial masyarakat. Dalam ajaran agama Hindu, hal yang paling mendasar untuk ditanamkan pada anak didik adalah pendidikan Tri Kaya Parisudha. Pendidikan Tri Kaya Parisudha secara substansi mengajarkan pada anak bagaimana

\footnotetext{
${ }^{13}$ Dosen Sekolah Tinggi Pariwisata Bali Internasional (STPBI) Denpasar
} 
berpikir, berkata, dan berbuat yang baik dan benar. Oleh sebab itu, dalam mengimplementasikan pendidikan Tri Kaya Parisudha haruslah dimulai sedini mungkin.

Tanu (2010:3) menjelaskan bahwa pendidikan dilaksanakan melalui tiga jalur yakni keluarga, sekolah, dan masyarakat. Oleh sebab itu peran keluarga, sekolah, dan masyarakat sebagai lingkungan atau basis utama tempat anak didik menerima pendidikannya harus dimaksimalkan. Dalam hal ini yang terpenting adalah bagaimana anak sebagai peserta didik menerima pembelajaran yang berorientasi pada pembentukan karakter secara baik dan benar. Anak didik harus dibiasakan sedini mungkin diajarkan untuk senantiasa berpikir, berkata dan berbuat yang baik sesuai ajaran Tri Kaya Parisudha. Apabila peranan dari ketiga lingkungan pendidikan tersebut berhasil dimaksimalkan, maka apa yang menjadi tujuan dari proses pembelajaran pendidikan tersebut yakni pembentukan kecerdasan dan kepribadian serta akhlak mulia kepada para peserta didik sebagai generasi muda bangsa dapat berhasil sesuai dengan apa yang diharapkan.

\section{PEMBAHASAN}

\subsection{Konsep Pendidikan Tri Kaya Parisudha.}

Berbicara mengenai pendidikan Tri Kaya Parisudha, tentunya tidak terlepas dari konsep dan tujuan pendidikan secara umum. Pendidikan dapat diartikan sebagai usaha yang dilaksanakan dengan sengaja oleh orang yang lebih tua (orang tua dan guru) untuk mempengaruhi orang lain (anak dan siswa) dengan mentransfer nilainilai tertentu kepada siswa, guna mempermudah siswa itu untuk memecahkan persoalan-persoalan hidup untuk mencapai tujuan hidupnya (Titib, 2003:13). Sumadi Suryasubrata (1982:12) menguraikan bahwa secara etimologi pendidikan berasal dari bahasa Yunani paedagogiek. Pais berarti anak, gogos berarti membimbing/tuntunan, dan eik berarti ilmu. Pendidikan merupakan kegiatan bersama memperoleh dan menyampaikan pengetahuan, sehingga memungkinkan penyebaran kebudayaan dari satu generasi ke generasi lainnya (Mudhyahardjo, 2002:3). Dengan demikian dapat ditegaskan bahwa pendidikan merupakan suatu upaya yang dilakukan dengan sengaja dan terencana dalam rangka membentuk intelektual dan kepribadian peserta didik.

Tri Kaya Parisudha dapat diartikan sebagai tiga tindakan manusia yang benar dan baik (Adiputra, 2003:65). Adapun pembagiannya adalah:

\subsubsection{Manacika (berpikir yang baik dan benar)}

Manacika Parisudha merupakan perilaku dari pikiran. Pikiran merupakan sumber dari segala bentuk perkataan maupun perbuatan manusia. Manusia dalam hidupnya selalu dituntut untuk menjaga kesucian hati dan pikirannya, serta menjauhkannya dari segala macam godaan hawa nafsu yang dapat memberikan pengaruh buruk pada ucapan dan perilaku seseorang. Dalam kitab Sarasamuscaya sloka 80 dinyatakan sebagai berikut:

Apan ikang manah ngaranya, ya ika withing indriya, maprawertti ta ya ring cubhacubhakarma, matangnyanikang manah ja prihen kahrtanya sakareng. 
Terjemahannya :

Sebab yang disebut pikiran itu, adalah sumbernya nafsu, ialah yang menggerakkan perbuatan yang baik ataupun yang buruk,oleh karena itu, pikiranlah yang segera patut diusahakan pengekangannya/pengendaliannya (Kadjeng dkk, 2007:44).

Pikiran mempunyai peranan yang sangat menentukan gerak dan perbuatan seseorang, oleh karena itu yang perlu diutamakan adalah pengekangan utama atau pengendalian pikiran sehingga segala perkataan maupun perbuatan senantiasa mengarah pada kebaikan dan hal-hal yang bersifat positif.

\subsubsection{Wacika (berkata yang baik dan benar)}

Wacika Parisudha merupakan ajaran etika yang berkaitan dengan ucapan atau perkataan. Perkataan mempunyai peranan yang sangat penting karena melalui perkataanlah manusia dapat berkomunikasi dan melakukan hubungan interaksi dengan sesamanya. Dalam hal ini anak didik harus senantiasa dituntun untuk berkata-kata yang baik, sopan dan benar. Sarasamuscaya sloka 132 menyatakan:

Kuneng lwir ingujarakena nihan, satya taya, hawya taya makawak hingsa, haywa makawak upet, hitawasana ta ya, haywa ta parusya, haywa pecunya, wangkana lwirining tan yogya ujarakena.

Terjemahannya:

Adapun kata-kata yang patut diucapkan, ialah : kata-kata yang mengandung kebenaran ; jangan berupa penusuk hati, jangan yang merupakan umpatan. Hendaknya kata-kata yang bermanfaat ; janganlah kata-kata yang kasar, jangan kata-kata yang terpengaruhi kemarahan, jangan kata-kata yang mementingkan diri sendiri, jangan kata-kata fitnahan ; demikianlah misalnya kata-kata yang tidak patut dikeluarkan (Kadjeng dkk, 2007:70).

Sebab itu anak didik hendaknya selalu dituntun untuk berbicara atau berkatakata berlandaskan pada ajaran-ajaran agama dan sesuai dengan norma-norma etika yang ada, sehingga perkataan yang diucapkan tidak menimbulkan sesuatu yang mengakibatkan kebencian atau kesalahpahaman dalam kehidupan bersama. Dengan perkataan yang baik, maka akan timbul rasa saling menghargai sehingga timbullah ikatan persaudaraan dan kekeluargaan yang kemudian membawa kebahagiaan bersama dalam kehidupan bermasyarakat, berbangsa, dan bernegara.

\subsubsection{Kayika (berbuat yang baik dan benar)}

Kayika Parisudha merupakan ajaran yang berkaitan dengan tingkah laku. Dalam kehidupan sehari-hari manusia hendaknya dapat menjauhkan diri dari segala macam perbuatan yang dilarang oleh agama maupun norma-norma yang berlaku di masyarakat. Perbuatan yang perlu untuk dihindari tersurat alam Sarasamuscaya sloka 76 sebagai berikut:

Nihan yang tan ulahakena, syamatimati mangahalahal, si paradara, nahan tang telu tan ulahakena ring asing ring parihasa, ring ring apatkala ri pangipyan tuwi singgajana jugeka. 
Terjemahannya:

Inilah yang tidak patut dilakukan: membunuh,mencuri, berbuat zinah; ketiganya itu janganlah hendaknya dilakukan terhadap siapapun, baik secara berolok-olok, bersenda gurau, baik dalam keadaan dirundung malang, keadaan darurat dalam khayalan sekalipun, hendaknya dihindari saja ketiganya itu (Kadjeng dkk, 2007:42).

Dalam hal ini manusia dalam hidupnya diharapkan untuk senantiasa berbuat yang baik dan benar, sesuai dengan ajaran Dharma. Agama Hindu mengajarkan bahwa perbuatan yang dilandasi oleh Dharma dapat mengantarkan manusia dalam mendapatkan kebahagiaan di dunia dan mencapai kesempurnaan.

Tujuan implementasi pendidikan Tri Kaya Parisudha bagi peserta didik tidak terlepas dari tujuan pendidikan agama Hindu itu sendiri. Dalam Himpunan Kesatuan Tafsir Terhadap Aspek-Agama Hindu dinyatakan bahwa tujuan pendidikan agama Hindu antara lain:

1. Tujuan pendidikan agama Hindu di luar sekolah yaitu:

a. Menanamkan ajaran agama Hindu itu menjadi keyakinan dan landasan segenap kegiatan umat dalam semua perikehidupannya.

b. Ajaran agama Hindu mengarahkan pertumbuhan tata kemasyarakatan umat Hindu hingga serasi dengan Pancasila Dasar Negara Republik Indonesia.

c. Menyerasikan dan menyeimbangkan pelaksanaan bagian-bagian ajaran agama Hindu dalam masyarakat antara Tattwa, Susila, dan Yadnya.

d. Untuk mengembangkan hidup rukun antara umat berbagai agama.

2. Tujuan pendidikan agama Hindu di sekolah yaitu:

a. Membentuk manusia Pancasilais yang astiti bhakti (bertaqwa) kepada Ida Sang Hyang Widhi Wasa atau Tuhan Yang Maha Esa.

b. Membentuk moral etika dan spiritual anak didik yang sesuai dengan ajaran agama Hindu (PHDI Pusat, 2006:23-24).

Beranjak dari hal tersebut maka, keluarga, sekolah, dan masyarakat sebagai setting pendidikan memegang peranan sentral dalam penanaman pendidikan Tri Kaya Parisudha terhadap pembentukan karakter peserta didik.

\subsection{Faktor-faktor Penyebab Kegagalan Pembentukan Karakter pada Peserta Didik}

Adapun faktor-faktor penyebab kegagalan pembentukan karakter pada anak didik dapat dipilah-pilah berdasarkan lingkungan tempat anak tersebut mendapatkan proses pendidikannya, yakni, keluarga, sekolah, dan masyarakat.

\subsubsection{Keluarga}

Keluarga merupakan tempat pertama dan paling utama tempat anak mendapatkan penanaman karakter, dari sejak dalam kandungan, hingga dewasa. Dalam hal ini, peran orang tua menjadi sangat penting, karena dari orang tualah anak didik akan memperoleh pendidikan pertamanya. Menurut Megawangi (2003:23) ada beberapa kesalahan orang tua dalam mendidik anak yang dapat mempengaruhi perkembangan kecerdasan emosi anak sehingga berakibat pada pembentukan karakternya, yaitu :

1. Kurang menunjukkan ekspresi kasih sayang baik secara verbal maupun fisik. 
2. Kurang meluangkan waktu yang cukup untuk anaknya.

3. Bersikap kasar secara verbal, misalnya menyindir, mengecilkan anak, dan berkata-kata kasar.

4. Bersikap kasar secara fisik, misalnya memukul, mencubit, dan memberikan hukuman badan lainnya.

5. Terlalu memaksa anak untuk menguasai kemampuan kognitif secara dini.

6. Tidak menanamkan "good character' kepada anak.

Dampak yang ditimbulkan dari salah asuh seperti di atas, menurut Megawangi (2003:24) akan menghasilkan anak-anak yang mempunyai kepribadian bermasalah atau mempunyai kecerdasan emosi rendah, diantaranya:

1. Anak menjadi acuh tak acuh, tidak butuh orang lain, dan tidak dapat menerima persahabatan. Karena sejak kecil mengalami kemarahan, rasa tidak percaya, dan gangguan emosi negatif lainnya. Ketika dewasa ia akan menolak dukungan, simpati, cinta dan respons positif lainnya dari orang di sekitarnya. la kelihatan sangat mandiri, tetapi tidak hangat dan tidak disenangi oleh orang lain.

2. Secara emosiol tidak responsif, dimana anak yang ditolak akan tidak mampu memberikan cinta kepada orang lain.

3. Berperilaku agresif, yaitu selalu ingin menyakiti orang baik secara verbal maupun fisik.

4. Menjadi minder, merasa diri tidak berharga dan berguna.

5. Selalu berpandangan negatif pada lingkungan sekitarnya, seperti rasa tidak aman, khawatir, minder, curiga dengan orang lain, dan merasa orang lain sedang mengkritiknya.

6. Ketidakstabilan emosional, yaitu tidak toleran atau tidak tahan terhadap stress, mudah tersinggung, mudah marah, dan sifat yang tidak dapat diprediksi oleh orang lain.

7. Ketidakseimbangan antara perkembangan emosional dan intelektual. Dampak negatif lainnya dapat berupa mogok belajar, dan bahkan dapat memicu kenakalan remaja, tawuran, dan lainnya.

8. Orang tua yang tidak memberikan rasa aman dan terlalu menekan anak, akan membuat anak merasa tidak dekat, dan tidak menjadikan orang tuannya sebagai "role model" Anak akan lebih percaya kepada "peer group"nya sehingga mudah terpengaruh dengan pergaulan negatif.

\subsubsection{Sekolah}

Dalam proses pembelajaran di sekolah, sudah barang tentu peranan tenaga pendidik lebih diutamakan. Dalam membangun hubungan yang harmonis dengan anak didik, serta membentuk kepribadian anak didik seorang guru sebagai pendidik dituntut tidak hanya pandai dalam menyampaikan materi, namun lebih menekankan pada pembentukan karakter peserta didik. Dalam penyampaian materi yang terpenting adalah bagaimana guru mengarahkan peserta didik tidak hanya sekedar mengerti apa yang disampaikan, namun mampu mengaplikasikannya dalam kehidupan sehari-hari anak didik. Wina Sanjaya (2010:92-93) menyatakan bahwa salah satu kekeliruan guru dalam mengajar adalah guru tidak mengajak berpikir kepada siswa. Komunikasi terjadi satu arah, yaitu dari guru ke siswa. Guru 
menganggap bahwa bagi siswa menguasai materi pelajaran lebih penting dibandingkan kemampuan berpikir dan bertindak. Orientasi pembelajaran lebih pada penyampaian materi. Keberhasilan suatu proses pengajaran diukur dari sejauh mana siswa dapat menguasai materi pelajaran yang disampaikan guru. Kadang-kadang siswa tak memahami apa gunanya mempelajari materi pelajaran tersebut.

\subsubsection{Masyarakat}

Masyarakat merupakan komunitas moral yang berbagi tanggung jawab untuk pendidikan mengembangkan karakter dan setia dan konsisten kepada nilai dasar yang diusung bersama-sama. Dalam lingkungan masyarakat terdapat sejumlah norma-norma yang ditaati bersama oleh seluruh anggota masyarakat. Masyarakat merupakan media bagi peserta didik dalam berinteraksi dan bersosialisasi dengan sesamanya. Simanjuntak (2003:156) menyatakan bahwa dalam proses sosialisasi seorang individu dari masa anak-anak sampai masa tua selalu belajar pola-pola tindakan dalam interaksi dengan segala macam individu sekitarnya yang menduduki beraneka macam peranan sosial. Dalam hal ini, adanya beberapa perilaku menyimpang dalam anggota masyarakat sebagai bentuk pelanggaran norma-norma akan mempengaruhi perkembangan kepribadian anak didik dimana hal tersebut dapat menjadi model yang cenderung diikuti dan ditiru oleh anak didik.

\subsection{Peran Keluarga, Sekolah, dan Masyarakat dalam Mengimplementasikan Pendidikan Tri Kaya Parisudha sebagai Landasan Pembentukan Karakter Peserta Didik}

Implementasi ajaran Tri Kaya Parisudha dalam pembentukan karakter anak didik tidak terlepas dari peran serta keluarga, sekolah dan masyarakat. Dalam hal ini yang terpenting adalah bagaimana anak sebagai peserta didik dapat mengikuti proses pembelajaran secara baik dan benar. Adapun peranannya masing-masing dapat diuraikan sebagai berikut:

\subsubsection{Peran Keluarga}

Keluarga merupakan lingkungan pendidikan yang primer dan fundamental sifatnya. Di situlah anak dibesarkan, memperoleh pertemuan awal dan belajar yang memungkinkan perkembangan selanjutnya bagi dirinya (Gunawan, 1996:16). Nasution (1987:131) menyatakan bahwa manusia tumbuh dan berkembang dari bayi yang tak berdaya dan dalam segala kebutuhannya bergantung pada orang lain menjadi manusia yang dapat menyesuaikan diri dengan berbagai corak ragam masyarakat. Artinya disini ditekankan bagaimana peran keluarga dalam membimbing dan membentuk kebribadian anak didik, sehingga nantinya menjadi orang yang berguna bagi masyarakat.

Salah satu fungsi keluarga adalah fungsi edukasi. Hartomo (2004:87-88) menyatakan bahwa fungsi edukasi merupakan konsekwensi yang logis daripada pemeliharaan anak-anak yang dilahirkan di dalam keluarga. Dari lingkungan keluarga inilah anak belajar berbahasa, mengumpulkan pengertian-pengertian dan menggunakan nilai-nilai kebudayaan yang berlaku. Didikan yang diberikan di dalam keluarga dalam masa kanak-kanak disesuaikan dengan daya tangkap dan sifat-sifat emosionalnya.

Kitab Suci Sarasamuscaya 242 memberikan secara rinci tentang tiga kewajiban orang tua yaitu sebagai berikut : 
1. Sarirakrta, yaitu kewajiban orang tua untuk menumbuhkan jasmani anak dengan baik.

2. Pranadatta, artinya orang tua wajib membangun atau memberikan pendidikan kerohanian kepada anak.

3. Anna Datta, yaitu kewajiban orang tua untuk memberikan pendidikan kepada anaknya untuk mendapatkan makanan (Anna) salah satu kebutuhan hidupnya yang paling essensial (Kajeng, 2007:122).

Dalam hal ini peran orang tua sebagai pendidik dalam keluarga merupakan peran yang penting. Sebab peran ini menyangkut perkembangan peran dan pertumbuhan pribadi anak. Orang tua sebagai pendidik terutama menyangkut pendidikan yang bersifat rasional. Dalam keluarga terjadi transformasi nilai-nilai, dimana nilai-nilai tersebut ditransformasikan ke dalam diri anak oleh orang tua. Penanaman pendidikan Tri Kaya Parisudha di tingkat keluarga dapat dilakukan dengan cara sebagai berikut:

1. Membiasakan sejak kecil anak-anak untuk berdoa dan melaksanakan Tri Sandhya secara teratur. Sikap yang demikian akan melatih anak untuk berpikir secara bijaksana. Kitab Rgveda VIII 69.8 menyatakan:

Sembah-sembahlah Dia (Tuhan Yang Maha Esa) dengan sepenuh hati wahai para pecinta pengetahuan, sembahlah dia. Beritahu anakanakmu....(Titib, 2003:105).

2. Senantiasa mengajarkan anak untuk berkata-kata dengan baik, dan sopan, serta hormat kepada orang yang lebih tua. Sikap yang demikian akan melatih anak untuk berkata dengan tutur kata yang baik.

3. Membiasakan diri anak untuk senantiasa terbuka kepada orang tua bila menghadapi suatu masalah. Sikap demikian untuk melatih kejujuran pada anak.

4. Membudayakan hidup bersih, seperti misalnya membersihkan badan, mencuci dan menyetrika pakaian. Sikap demikian melatih anak untuk mandiri dan bertanggung jawab.

5. Menanamkan sikap disiplin pada anak. Orang tua hendaknya tidak terlalu permissive (longgar) pada anak, yang menyebabkan anak menjadi ketergantungan. Kitab Canakya Niti Darpana II.12 menyatakan bahwa:

Terlalu banyak kelonggaran akan mengakibatkan banyak kesalahan, sedangkan ketegasan (disiplin) akan membentuk watak yang baik, karena itu bersikaplah tegas kepada anak atau para siswa, jangan memberi kelonggaran (Titib, 2003:40).

Dengan penerapan disiplin yang baik akan membiasakan anak untuk berbuat yang baik dan sesuai dengan norma yang berlaku, sehingga nantinya kebiasaan tersebut akan menjadi landasan anak didik dalam berbuat baik di keluarga, sekolah dan masyarakat.

\subsubsection{Peran Sekolah}

Lingkungan sekolah pada dasarnya merupakan lingkungan formal yang pertama bagi seorang anak. Melalui sekolah, seorang anak dituntut untuk berdisiplin mengikuti aturan, menerima hukuman, dan pujian atas prestasinya (Hartomo, 
2004:132-133). Dalam perspektif Hindu, kitab Atharvaveda XI.5.14 mejelaskan sebagai berikut:

\section{Acaryo mrtyur varunah \\ Soma osadhayah payah}

Terjemahannya:

Kepala sekolah hendaknya keras bagaikan Yama, seorang hakim bagaikan dewa Varuna, pemberi semangat hidup bagaikan dewa Soma, penghancur sifatsifat buruk bagaikan tumbuh-tumbuhan yang berkhasiat obat dan penyegar bagi air (Titib, 1996:435).

Wina Sanjaya (2010:99-100) menyatakan bahwa proses pembelajaran di sekolah hendaknya berorientasi pada lingkungan dengan salah satu karakteristiknya adalah pembelajan yang berorientasi pada tujuan, dimana tujuan pembelajaran bukanlah penguasaan materi pelajaran, akan tetapi proses untuk mengubah tingkah laku siswa sesuai dengan tujuan yang ingin dicapai. Oleh karena itu, penguasaan materi pelajaran bukanlah akhir dari proses pengajaran, akan tetapi hanya sebagai tujuan antara untuk pembentukan tingkah laku yang lebih luas.

Terkait dengan hal ini, H. Dakir (2004:27-28), menyatakan bahwa terdapat sembilan aspek yang menjadi prioritas utama pembelajaran di sekolah yakni:

1. Ketaqwaan.

Manusia berasal dari Tuhan, perlu bertaqwa pada pencipta-Nya, tetapi yang ditekankan dalam hal ini adalah jangan sampai bersifat fanatik dan dogmatis.

2. Kecerdasan.

Aspek pribadi dari cipta yang berpusat di otak perlu dikembangkan, tetapi jangan sampai bersifat rasionalistis.

3. Kesusilaan.

Aspek pribadi dari karsa yang bersifat di hati, perlu dibina, tetapi jangan bersifat emosionalistis.

4. Kejujuran.

Aspek pribadi dari karsa yang menyebabkan kita berkemampuan untuk berbuat, perlu bimbingan yang positif, tetapi jangan sampai bersifat voluntaristis.

5. Kekreatifan.

Karya yang harmonis dari ketiga aspek cipta, rasa, dan karsa akan menghasilkan sesuatu yang baru, perlu dilatih dan dibina sesuai dengan bakat dan minat anak, tetapi jangan sampai bersifat sombong.

6. Kesehatan.

Aspek yang sangat dibutuhkan oleh raga, perlu dilatih dan dibiasakan hidup sehat, tetapi jangan sampai bersifat animalistis.

7. Keterampilan.

Karya dari raga, terutama dalam latihan otot perlu dilatih agar para siswa dapat prigel dan dapat hidup mandiri, tetapi jangan bersifat kurang pertimbangan akal.

8. Kemasyarakatan.

Manusia tidak pernah hidup sendiri, pasti butuh pertolongan orang lain, hidup bermasyarakat perlu dibina, tetapi jangan sampai bersifat altruistis.

9. Kemandirian. 
Manusia sebagai makhluk individu mempunyai sifat individual, berbeda antara satu dengan yang lain, perlu dibina terutama dalam bakat dan minatnya hendaknya dijaga jangan sampai menjadi manusia egois.

Penanaman pendidikan Tri Kaya Parisudha di lingkungan sekolah sesungguhnya telah terintegrasi dalam kurikulum mata pelajaran di sekolah. Seorang guru tidak hanya dituntut mengembangkan kecerdasan, namun juga menanamkan karakter dan pembentukan sikap dan akhlak yang baik, sehingga dalam memberikan penilaian tidak hanya melihat aspek kecerdasan intelektual semata, namun yang terpenting adalah melihat aspek kepribadian yang diukur dari segi cara berpikir, cara berkata, maupun tingkah lakunya di sekolah. Dengan demikian hal ini akan memotivasi peserta didik dalam mengembangkan sikap dan perilakunya ke arah yang lebih baik.

\subsubsection{Peran Masyarakat}

Lingkungan yang tidak kalah pentingnya dalam membentuk kepribadian anak didik adalah lingkungan masyarakat. Menurut Linton (dalam Hartomo, 2004:88), masyarakat adalah setiap kelompok manusia yang telah cukup lama hidup dan bekerja sama, sehingga mereka itu dapat mengorganisasikan dirinya dan berpikir tentang dirinya sebagai satu kesatuan sosial dalam batas-batas tertentu. Masyarakat dalam hal ini berfungsi sebagai tempat anak didik bergaul dan bersosialisasi. Dalam setiap masyarakat, pewarisan budaya terjadi melalui proses sosialisasi. Individu sebagai anggota masyarakat mendapat pembentukan sikap untuk berperilaku sesuai dengan perilaku masyarakat (Simanjuntak, 2003:167).

John Locke (dalam Utama 2005:28) berpendapat bahwa dalam perkembangan anak menjadi dewasa ditentukan oleh lingkungannya atau oleh pendidikan dan pengalaman yang diterimanya sejak kecil. Dalam hal ini, masyarakat merupakan tempat anak didik sebagai individu yang mendapat proses pendidikan melalui pergaulan, maupun norma-norma yang berlaku dalam sistem masyarakat itu sendiri..

Penanaman pendidikan Tri Kaya Parisudha dalam pembentukan karakter pada anak didik beberapa diantaranya yang dapat diupayakan adalah:

1. Mengembangkan sikap saling menghormati antar anggota masyarakat. Hal ini akan membuat kedudukan peserta didik dalam masyarakat tempatnya berada merasa dihargai. Rgveda I.27.13 menyatakan sebagai berikut:

Namo mahadbhyo, namo arbhakebhyo,

Namo yuvabhyo, nama asinebhyah.

Terjemahannya:

Hormatku pada para orang tua, para pemuda, kaum muda (anak-anak), dan orang-orang yang sudah berusia lanjut (Titib, 1996:424).

Hal demikian akan berimplikasi pada tingkah laku yang baik pada anak didik, baik dalam berpikir positif, berkata, maupun dalam tindakannya sehari-hari dalam berinteraksi.

2. Mengefektifkan penegakan norma-norma yang berlaku di masyarakat. Hal ini dimaksudkan agar anggota masyarakat, termasuk didalamnya peserta didik untuk senantiasa menghindari perilaku-perilaku yang menyimpang. Dalam hal ini peranan tokoh-tokoh masyarakat sangat penting karena menjadi figur contoh yang diteladani oleh anggotanya. Implikasinya pada peserta didik 
adalah untuk memacu sikap yang taat dan berpegang teguh pada aturan yang berlaku, serta memupuk jiwa persatuan dan kesatuan peserta didik sebagai bagian dari masyarakat itu sendiri. Kitab Atharvaveda III.8.5 menyatakan bahwa:

Tuhan Yang Maha Esa menciptakan manusia supaya hidup serasi, menjauhkan diri dari perbuatan buruk, hendaknya seseorang mampu mengendalikan diri dan memiliki disiplin yang tinggi sehingga tumbuh keselarasan, saling pengertian dan tanggung jawab bersama (Titib,2003:119).

Hal ini berarti peran serta masyarakat untuk membentuk karakter anak didik sangat penting, sehingga untuk kedepannya anak didik sebagai bagian dari masyarakat itu sendiri dapat menjadi manusia yang lebih beradab, taat pada norma-norma yang berlaku dan memiliki kepribadian, serta akhlak mulia, sehingga pada akhirnya dapat membawa bangsa dan negara ke arah yang lebih baik.

\section{III.PENUTUP}

\subsection{Simpulan}

Pendidikan Tri Kaya Parisudha merupakan salah satu pengaplikasian ajaran agama Hindu dalam menumbuh kembangkan perilaku peserta didik untuk senantiasa berpikir, berkata, dan berbuat yang baik. Implementasi pendidikan Tri Kaya Parisudha dalam pembentukan karakter anak didik tidak terlepas dari peran serta keluarga, sekolah dan masyarakat. Peran keluarga dalam mengimplementasikan pendidikan Tri Kaya Parisudha yakni membiasakan anak untuk berdoa, terbuka pada orang tua, menghormati orang tua, serta menegakkan disiplin pada anak sejak usia dini. Penerapan pendidikan Tri Kaya Parisudha di lingkup sekolah yakni mengefektifkan proses pembelajaran dengan tidak hanya berorientasi pada kecerdasan intelektual, namun juga berorientasi pada perubahan tingkah laku, sehingga output sekolah yang dihasilkan tidak hanya memiliki pengetahuan yang tinggi, namun memiliki karakter yang baik dan akhlak yang mulia. Dalam lingkup masyarakat, implementasi pendidikan Tri Kaya Parisudha dilakukan dengan menumbuhkan sikap saling menghormati dan menghargai antar sesama anggota masyarakat dengan tidak mementingkan golongan tertentu, baik anak-anak, kaum tua, maupun muda, serta menegakkan norma-norma yang berlaku sebagai pedoman dalam bertingkah laku di masyarakat. Peran serta masyarakat untuk membentuk karakter anak didik sangat penting, sehingga untuk kedepannya anak didik sebagai bagian dari masyarakat itu sendiri dapat menjadi manusia yang lebih beradab, taat pada norma-norma yang berlaku dan memiliki kepribadian, serta akhlak mulia, sehingga pada akhirnya dapat membawa bangsa dan negara ke arah yang lebih baik.

\section{DAFTAR PUSTAKA}

Dakir, H. 2004. Perencanaan dan Pengembangan Kurikulum. Jakarta: PT Rineka Cipta

Gunawan, Ary H. 1996. Administrasi Sekolah. Jakarta: Rineka Cipta.

Hartomo, H dan Arnicun Aziz. 2004. Ilmu Sosial Dasar. Jakarta: Bumi Aksara

Kajeng, I Nyoman, dkk. 2007. Sarasamuscaya. Pemerintah Provinsi Bali 
Megawangi, Ratna. 2003. Pendidikan Karakter untuk Membangun Masyarakat Madani. IPPK Indonesia Heritage Foundation (Online).

Mudyahardjo, Radja. 2002. Pengantar Pendidikan Sebuah Studi Awal Tentang Dasar-Dasar Pendidikan pada Umumnya dan Pendidikan di Indonesia. Jakarta: Raja Grafindo Persada.

Nasution, S. 1987. Berbagai Pendekatan dalam Proses Belajar Mengajar. Jakarta: Bina Aksara.

Parisada Hindu Dharma Indonesia Pusat. Himpunan Kesatuan Tafsir Terhadap Aspek-aspek Agama Hindu. Pemerintah Provinsi Bali.

Sanjaya, Wina. 2010. Strategi Pembelajaran Berorientasi Standar Proses Pendidikan. Jakarta: Kencana.

Sedhawa, I. B. 2006. Membangun Budaya Rohani Menuju Keluhuran Budi. Denpasar : Pemerintah Provinsi Bali.

Simanjuntak, Posman. 2003. Antropologi. Jakarta: Erlangga.

Suryasubrata, Sumadi. Dasar-dasar Kependidikan. Jakarta: Rineka Cipta.

Tanu, I Ketut. 2010. Konsep dan Makna Pembelajaran di Era Global. Denpasar: Sari Kahyangan Indonesia.

Titib, I Made. 1996. Veda Sabda Suci Pedoman Praktis Kehidupan. Surabaya : Paramita.

2003. Menumbuhkembangkan Pendidikan Budi Pekerti pada Anak. Jakarta: Ganeca Exact.

Undang-Undang Sisdiknas No.20 Tahun 2003. 2010. Jakarta: Bening.

Utama, I Gst Ayu Agung Wira Putri. 2005. Kajian Tentang Aplikasi Kurikulum Berbasis Kompetensi dalam Pembelajaran Agama Hindu di SMA Dwijendra Denpasar (Skripsi). Denpasar: Institut Hindu Dharma Negeri Denpasar 